\title{
How Does the Market for Corporate Control Function for Property Companies?
}

\author{
Piet M. A. Eichholtz • Nils Kok
}

Published online: 3 August 2007

(C) Springer Science + Business Media, LLC 2007

\begin{abstract}
We investigate 95 takeovers of property companies all over the world and find that only two of those are hostile. To determine the effectiveness of the market for corporate control, we first study characteristics of targets and acquirers compared to a control sample, using the complete global universe of listed property companies during the most recent takeover wave (1999-2004). We find that the inefficient management hypothesis holds for both REITs and non-REITs, as targets exhibit significant underperformance before takeovers. In the second part of this study, we investigate shareholder wealth effects following takeovers and confirm previous findings that abnormal returns for targets and bidders are distinctly different for the real estate sector. Moreover, we show that this difference not only holds for REIT-toREIT mergers, but also for mergers of real estate firms without a REIT-status.
\end{abstract}

Keywords Corporate governance $\cdot$ Mergers and acquisitions $\cdot$ Real estate

JEL Classification $\mathrm{G} 32 \cdot \mathrm{G} 34$

\section{Introduction}

The driving forces of the takeover market have long been subject to academic interest. Potential motives for takeovers ${ }^{1}$ include taxes, increase of market power, diversification of operations, creating synergies, undervaluation of targets and wealth transfers to stockholders from bondholders or employees (Agrawal and Jaffe 2003). From a governance point of view, the market for corporate control is generally regarded as an important disciplinary force (Jensen 1988): the threat of a takeover might reduce the agency problem by stimulating agents to take decisions that are in line with the principals' interest and an actual takeover provides an

\footnotetext{
${ }^{1}$ We use the terms merger, acquisition and takeover interchangeably throughout the paper.

P. M. A. Eichholtz $(\bowtie) \cdot$ N. Kok

Department of Finance, Faculty of Economics and Business Administration, Maastricht University, P.O. Box 616, 6200MD Maastricht, The Netherlands

e-mail: p.eichholtz@finance.unimaas.nl
} 
acquiring firm with the opportunity of restructuring an underperforming target. This is usually referred to as the inefficient management hypothesis and is regarded as a prominent motive for takeovers in the literature.

The inefficient management hypothesis has been tested from two different perspectives. The first approach measures target performance prior to the takeover announcement, using either stock returns or operating measures of performance. Regarding this approach, there is no consensus in the literature to whether the inefficient management hypothesis holds (Agrawal and Jaffe 2003; Schleifer and Vishny 1986). The second approach tests target and bidder performance around and after the announcement of the takeover bid. If a takeover indeed corrects failing managers, the stock return of both acquirers and targets should improve around and after the bid announcement. In line with expectations, positive total wealth effects are consistently documented, but wealth effects to acquirers are generally documented to be negative.

This paper elaborates on the inefficient management hypothesis by focussing on the real estate sector specifically, which is of interest for several reasons. First, the real estate sector is characterized by a lack of hostile takeovers. This was first documented for a real estate takeover wave in the 1980s by Allen and Sirmans (1987), who find that only one event could be classified as a hostile takeover. Moreover, in a follow-up study, Campbell et al. (2001) find no hostile takeovers at all in their sample, which covers the 1990-1994 period. The absence of hostile takeovers in the property sector is contrasting to empirical evidence found for other sectors; several studies document that hostile takeovers occur frequently (Agrawal and Jaffe 2003; Morck et al. 1998; Servaes 1991). This might indicate that the market for corporate control differs from other sectors and that it may not function properly for the real estate sector. We will investigate this issue further.

Secondly, the inefficient management hypothesis has only been tested partially for the real estate sector, as to our knowledge no study exists that investigates prior performance of takeover targets in the real estate sector. Moreover, wealth effects following takeovers have been studied, but the findings are different in magnitude and sign compared to other sectors (Allen and Sirmans 1987; Campbell et al. 2001). This yields the necessity for a detailed study of the takeover market in the real estate sector, a gap in the empirical knowledge that will be filled by this paper.

Thirdly, corporate governance issues in the real estate sector are especially of interest, because of the experimental laboratory offered by REITs. The real estate sector might be less vulnerable to agency problems, due to the possibility for property companies in several countries to transform into a structure comparable to the US Real Estate Investment Trust (REIT). In this legal framework, up to $100 \%$ of the free cash flow is distributed to the shareholders in exchange for a $0 \%$ corporate tax rate and moreover, restrictions can be imposed on the use of leverage and the structure of the investor base. ${ }^{2}$ The unique institutional setting in which REITs

\footnotetext{
${ }^{2}$ The REIT structure is available or will be available shortly in 23 countries, including: USA, Canada, Australia, Hong Kong, Japan, South-Korea, Singapore, Belgium, France, Italy, and The Netherlands. More countries, such as the UK and Germany are expected to follow. REITs have a $0 \%$ corporate tax rate, provided that they comply with certain regulations. These are country specific, but generally involve requirements with respect to the composition of the asset portfolio, distribution of profits, shareholder requirements and financial structure. See Op 't Veld (2005) for a detailed description of REIT characteristics internationally.
} 
operate leads to a situation in which the free cash flow problem is less of an issue, thereby reducing agency problems. On the other hand, the imposed dispersion of ownership might obstruct takeovers (Ghosh and Sirmans 2003). In our detailed study on the functioning of the real estate takeover market, we will make a comparison between takeovers of REITs and takeovers of real estate companies without a REITstatus to investigate how the REIT structure affects the inefficient management hypothesis.

Lastly, we test whether the inefficient market hypothesis holds for the real estate sector using an international sample of 95 takeovers over the 1999-2004 period. We first analyze the financial characteristics of targets and elaborate on existing studies by also taking other variables than performance characteristics into account. Furthermore, we include an analysis on the characteristics of bidders. Finally, we compare targets, acquirers and a control sample using a multinomial logistic approach and find that, although hostile takeovers are rare in the real estate sector, the takeover market seems to work effectively as targets are mainly financially underperforming, small companies that have a low market-to-book value. Moreover, the financial underperformance of targets seems to hold for REITs as well as nonREITs.

As a second test of the inefficient market hypothesis, we perform an event study on abnormal returns surrounding the bid announcement, which shows weak but consistent results supporting the inefficient management hypothesis, because the positive total wealth effects we document indicate that shareholders perceive takeovers to be valuecreating rather than value-destroying. We find evidence that shareholder returns for bidders in the real estate sector are around zero, which is relatively high compared to findings in the corporate finance literature. Abnormal returns to targets are significantly positive, although the scope is smaller compared to results previously documented in the existing finance literature. Finally, the legal structure of targets plays a distinctive role in the scope of wealth effects following takeovers.

The rest of this paper is organized as follows. "Literature Review: The Inefficient Management Hypothesis" provides a short literature overview in which we first discuss studies on pre-acquisition performance of targets. Secondly, we review the literature on wealth effects following takeovers. "Data" presents the data and descriptive statistics. "Drivers of the Takeover Market" discusses the methodology and results on the analysis of characteristics of targets and bidders compared to a control sample. First, pre-acquisition performance of targets is studied, followed by a univariate analysis and finally a multinomial logistic regression. In "Wealth Effects Following Takeovers," the results on the analysis of shareholder wealth effects following takeovers are presented, while the paper ends with a summary and discussion of conclusions in "Conclusions and Discussion."

\section{Literature Review: The Inefficient Management Hypothesis}

Pre-acquisition Performance of Targets

The inefficient management hypothesis states that inefficient allocation of resources might lead to underperformance and therefore, takeover activity is believed to be 
motivated by the desire to improve the targets' performance by improving the targets' management (Agrawal and Jaffe 2003). Evidence of the practical application of this theory is mixed and a comprehensive review is provided in the Appendix of Agrawal and Jaffe (2003).

In studies which specifically address prior stock performance of targets in mergers, the evidence for the efficient management hypothesis is not compelling, as only one study finds significantly negative abnormal return (Asquith et al. 1983) whereas seven others do not (Agrawal and Jaffe 2003; Agrawal and Walkling 1994; Asquith and Kim 1982; Ellert 1976; Langetieg 1978; Malatesta 1983; Mandelker 1974). It might be expected that hostile takeovers - often tender offers - rather than friendly mergers are triggered by poor performance, but in five studies (Dodd and Ruback 1977; Franks and Mayer 1996; Kini et al. 2004; Martin and McConnell 1991; Smiley 1976) on target performance in tender offers, only Smiley finds that targets exhibit significantly negative pre-acquisition performance.

Several other studies try to explain takeover probability by using predicting models and public data, including financial performance measures. For operating measures of performance, the evidence of underperformance leading to an increased takeover probability is insignificant as documented by Palepu (1986), Song and Walkling (1993) and Berger and Ofek (1996), whereas Morck et al. (1998), Barber et al. (1994), Graham et al. (2002) find that poor performance leads to a higher probability of becoming a target. With respect to stock measures of performance Palepu (1986) finds a negative relationship between prior stock performance and probability of acquisition, whereas Morck et al. (1998) document no significant influence of abnormal returns on the probability of neither hostile nor friendly acquisition.

Finally, some papers do not specifically study performance of targets, but use other measures that are related to the inefficient management hypothesis, mostly related to corporate governance, for example board composition and ownership structure (Ambrose and Megginson 1992; Mitchell and Lehn 1990; Morck et al. 1998; North 2001; Shivdasani 1993; Song and Walkling 1993; Weir and Laing 2003). Although some of the studies indeed support the inefficient management hypothesis, Agrawal and Jaffe (2003) note that corporate governance variables might as well constitute direct evidence due to the correlation with firm performance.

The existing base of literature does not provide consistent evidence in favour of the efficient management hypothesis. Moreover, no specific research for the real estate sector has taken place hitherto. The first part of our analysis will therefore focus on operating and financial measures of performance of targets prior to takeover bids. Moreover, we will control for variables that might have an influence on takeover probability, such as board composition, ownership structure and asset characteristics. Finally, we broaden our analysis to the characteristics of bidders to get a complete insight in what exactly drives takeovers in the real estate sector.

\section{Shareholder Wealth Effects Following Takeovers}

If the efficient management hypothesis holds and thus the objective of a takeover is to correct for managerial failure, we would not only expect target firms to show poor performance prior to a takeover bid, but we would also expect positive post-takeover Springer 
wealth effects for bidders and targets. Hitherto, several perspectives on wealth effects following takeovers have been studied in finance literature, thereby addressing specific issues such as method of payment (Franks et al. 1988; Travlos 1987), identity of target (Chang 1998), methodology (Asquith et al. 1983), firm size (Moeller et al. 2004), and the impact of sector-specific characteristics (Allen and Sirmans 1987; Subrahmanyam and Rangan 1997).

In general, the inefficient management hypothesis is supported by the consistently significant and positive cumulative abnormal returns (CAR) documented for targets. For example, Servaes (1991) documents a CAR of $20.5 \%$ for all-equity acquisitions and a CAR of $26.7 \%$ for cash bidders, Dodd (1980) reports a $13.4 \%$ CAR for a sample of takeover targets including all methods of payment. For the real estate sector, McIntosh et al. (1989) report lower gains to bidding firms with a CAR of $6.2 \%$. Campbell et al. (2001) also find positive (3.0\%), but relatively low returns to target shareholders. Campbell (2002) explains these findings by the fact that the market for corporate control is not very powerful in the listed real estate sector, as hostile takeovers are completely absent. Moreover, Sirmans (1997) suggests that corporate governance structures might be less efficient in REITs due to institutional restrictions, leading to advantages of synergy in mergers to flow to managers rather than shareholders. These findings indicate that the inefficient management hypothesis might hold to a lesser extent for the real estate sector than for other sectors.

If bidders would act in line with the inefficient management hypothesis and only acquire underperforming companies, the abnormal return for bidders following acquisition announcements is expected to be positive as well. However, there is a consensus in the literature that bidders hardly show significantly positive abnormal returns. Within others, Asquith et al. (1983) find cumulative abnormal returns (CARs) of $-2.4 \%$, and Travlos (1987) documents a CAR of $-1.7 \%$. Moreover, shareholder wealth effects accruing to bidders are negatively influenced by stock as a method of payment, which is often explained by the information signalling theory of Myers and Majluf (1984). There are some exceptions to the negative effect on shareholder wealth of acquiring companies following stock bids; Chang (1998) shows that in takeovers of private firms, stock as a method of payment leads to positive acquirer returns. This finding is explained by the positive monitoring effect due to creation of blockholders in the merged entity and the positive signal of the willingness of well-informed investors to take a substantial position in an acquiring firm. The second exception to negative returns for stock-bidders is a study by Allen and Sirmans (1987), who find nonnegative performance effects for bidders if stock is used as a method of payment in takeovers. This finding is explained by the reduced cash-generating ability of REITs.

In a recent study, Campbell et al. (2001) extend the studies of Chang (1998) and Allen and Sirmans (1987), by exploring the influence of method of payment in both public-public and public-private takeovers in the REIT-sector. In contrast to Allen and Sirmans, they find that stock acquisitions in public-to-public REIT mergers lead to slightly negative results, although the scope of these results is smaller than found by other studies. Consistent with Chang, they find a positive shareholder wealth effect following stock bids on private targets. 
The real estate sector with its unique institutional environment has yielded inconsistent results with respect to shareholder wealth effects following takeovers. Therefore, we use a global sample of takeovers including the United States, but also other important real estate markets, such as the UK, The Netherlands and Australia. This sample allows us to determine whether the distinct abnormal returns documented for the real estate sector hitherto are REIT or rather real estate specific.

\section{Data}

\section{Data and Methodology}

Our initial sample consists of 145 takeovers during the 1999-2004 period. These were identified using data obtained from Global Property Research (GPR) and include all takeovers involving a public target. ${ }^{3}$ Contrasting Chang (1998) and Campbell et al. (2001) we do not include takeovers of privately held companies. This is mainly because data on takeovers of private real estate targets is hardly available internationally, which also holds for financial and other information regarding private firms. ${ }^{4}$

Transactions on which no financial information could be found or that appeared to be cancelled or still pending were deleted from the sample. Moreover, the inclusion of small and less liquid stock markets in our analyses might introduce noise rather than improve the significance of our findings. ${ }^{5}$ Therefore, we use a reduced sample throughout the paper. This sample contains 95 takeovers - of which 51 have a public acquirer. Countries included are: USA, Canada, UK, Australia, Sweden and The Netherlands.

In order to get a better insight in the drivers of mergers and acquisitions, we match the targets and acquirers to a control firm using a temporal matching approach following Ambrose (1990). The control sample consists of all listed real estate firms in the selected countries, with a minimal market capitalization of $\$ 50 \mathrm{M}^{6}{ }^{6}$ From this sample firms are excluded if (1) they are involved in mergers and acquisitions during the sample period, (2) they are not continuously listed, or (3) the required data is not available. This leads to a control sample of 103 firms, allowing a control firm to be in the sample more than once.

Following Franks and Mayer (1996), we examine how long-run pre-acquisition stock performance differs between targets and non-targets. Moreover, we investigate

\footnotetext{
${ }^{3}$ The sample includes real estate operating companies and REITs, but excludes pure construction and development companies.

${ }^{4}$ We recognize the potential sample bias of not including transactions including private targets, but as we are interested in stock and operating performance of targets, private targets are less of interest due to nonavailability of this performance data.

${ }^{5}$ We repeat our analyses using both the complete sample and the sample that includes a selection of markets only. The results indeed seem to benefit from the exclusion of small markets.

${ }^{6}$ The control sample is provided by GPR and does not include pure construction and development companies.
}

望 Springer 
the impact of performance on the likelihood of being involved in a takeover, either as a target or as an acquirer, while controlling for the impact of other variables. We use a selection of financial characteristics based on studies described in the literature review, in particular (Palepu 1986). These variables include leverage, valuation, size, dividend yield, cash holdings and selling expenditures. Moreover, we include governance and asset characteristics as control variables, where selection of variables is based on existing studies as well. More specifically, we include managerial ownership (North 2001; Song and Walkling 1993), block ownership (Schleifer and Vishny 1986), independence of the board (Shivdasani 1993; Weir 1997) and portfolio characteristics (Campbell et al. 2001). All variables and their respective sources are listed in Appendix.

The required financial data are obtained from Datastream, Worldscope and Thomson Research, whereas details on portfolio composition and ownership structure are handcollected from proxy statements, annual reports and GPR Handbooks. In line with Ambrose (1990), data is collected around an 'information date', which is assumed to be exactly half a year before the announcement date $t$ of a merger or acquisition. In order to correct for extreme observations, values for daily measured variables are calculated over a 130-trading day period around the information date and yearly measured variables are calculated as an average value of the last three years before the announcement date. Stock performance prior to takeovers is measured on a monthly basis for various intervals.

\section{Descriptive Statistics}

A first analysis of the data reveals the striking finding that our sample includes only two hostile takeovers. This number is relatively small in a sample of 95 takeovers during the 1999-2004 time period, but is consistent with earlier findings for the real estate sector as documented by Allen and Sirmans (1987), Campbell et al. (2001) and Campbell (2002). Explanations for the absence of hostile takeovers in the real estate sector can be twofold: there is a reduced need for incentive and monitoring mechanisms in the restricted REIT environment, or, the restricted investor environment of REITs obstructs hostile takeovers (Ghosh and Sirmans 2003). However, our sample does not support either of these arguments, since hostile takeovers are also absent in markets without the REIT structure. The lack of hostile takeovers therefore seems to be a real estate issue rather than a REIT issue. Further discussion of this finding is provided in "Conclusions and Discussion."

Table 1 shows that the sample contains transactions from six different countries, of which the majority has taken place in the USA, the UK and Australia. Furthermore, almost half of the mergers and acquisitions involve private acquirers, which is due to the fact that the real estate sector still consists of a larger non-listed than listed sector, especially in Europe. Taking a closer look at the private bidders in Europe, we find a high number of management buyouts in the UK, which might be explained by the discounts to NAV that are frequently observed for UK listed property companies over the sample period (Brounen and ter Laak 2005).

Due to the small number of observations, our sample does not include takeovers taking place in the relatively large listed real estate markets of Asia (e.g. Japan, Hong Kong, South Korea). The low takeover activity may well be explained by the 
Table 1 Characteristics takeover sample (1999-2004)

\begin{tabular}{|c|c|c|c|c|c|c|c|c|}
\hline \multirow[t]{2}{*}{ Country } & \multirow{2}{*}{$\frac{\text { Universe }}{\#}$} & \multicolumn{2}{|c|}{ Targets acquirers } & \multicolumn{3}{|c|}{ Method of payment } & \multicolumn{2}{|c|}{ Deal value (\$M) } \\
\hline & & \# & Listed & Cash & Stock & Mix & Mean & SD \\
\hline \multicolumn{9}{|l|}{ North America } \\
\hline USA & 139 & 31 & 20 & 15 & 12 & 4 & 822.3 & 802.7 \\
\hline Canada & 22 & 6 & 2 & 4 & 1 & 1 & 341.2 & 304.6 \\
\hline \multicolumn{9}{|l|}{ Europe } \\
\hline The Netherlands & 9 & 6 & 4 & 4 & 2 & 0 & 949.2 & 774.9 \\
\hline Sweden & 13 & 9 & 2 & 9 & 0 & 0 & 401.7 & 402.0 \\
\hline UK & 41 & 29 & 4 & 25 & 2 & 2 & 933.1 & 1747.1 \\
\hline \multicolumn{9}{|l|}{ Asia (Pacific) } \\
\hline Australia & 26 & 14 & 19 & 5 & 5 & 4 & 563.5 & 453.9 \\
\hline Totals $(\%)$ & 250 & $100 \%$ & $51 \%$ & $62 \%$ & $22 \%$ & $11 \%$ & 908.1 & 1087.8 \\
\hline
\end{tabular}

This table provides descriptive statistics on the takeovers in our sample. We match all deals in the different countries to the complete universe of property companies in every country (market cap $>\$ 50 \mathrm{M}$, source: GPR) to get insight in the relative national takeover activity. All targets are publicly listed, for acquirers the number of listed firms is provided. We distinguish three methods of payment: cash, stock and mixed. Deal value denotes the average deal value in US\$M

institutional structure in these countries: most of the property companies are part of a larger conglomerate (e.g. keiretsu or chaebol), which usually owns a majority of the shares.

Only ten deals in our sample are cross-border. The reason for international diversification still taking place on a relatively small scale might be the underperformance real estate firms investing internationally as compared to firms investing locally (Eichholtz et al. 2001). Eight out of ten international acquisitions involve an acquirer or target from continental Europe, mostly originating from The Netherlands. The relatively small size of listed real estate markets in continental Europe compared to the USA and the UK yields the necessity for European property companies for cross-border acquisitions. Moreover, there is great potential for deals within the European Union due to increasing integration of the fragmented national economies into one single market.

The cyclical nature of merger and acquisition activity in the real estate sector as described by Campbell (2002) is reflected in Table 2, which shows a clear peak in

Table 2 Distribution of takeovers over the sample period

\begin{tabular}{lcc}
\hline Year & Deals & \\
\cline { 2 - 3 } & $\#$ & $\%$ \\
\hline 1999 & 8 & 8.4 \\
2000 & 33 & 34.7 \\
2001 & 24 & 25.3 \\
2002 & 14 & 14.7 \\
2003 & 13 & 13.7 \\
2004 & 3 & 3.16 \\
Total & 95 & 100 \\
\hline
\end{tabular}

This table shows the distribution of takeover announcements over the sample period in absolute and relative numbers 
acquisition announcements for the years 2000 and 2001, in which almost two-third of the acquisitions took place. This could be related to the bearish sentiment on the stock market at those times, which lead to low market-to-book values of property companies. With respect to possible seasonal effects, we find no distinct pattern in the distribution over the quarters. Finally, Fig. 1 provides insight in the time to completion of takeovers in the sample. The time to completion reflects the period between announcement of the takeover and final acquisition of the shares of the target. As our sample almost completely exists of friendly takeovers, the average completion time is short, about 3.5 months, with a majority of the deals closed in less than half a year, which is in line with findings by Allen and Sirmans (1987). Further analysis of the relationship between method of payment and the time to completion reveals that a cash bid leads to a shorter time to completion than alternative methods of payment.

\section{Drivers of the Takeover Market}

Pre-acquisition Performance

If the inefficient management hypothesis holds and the takeover market functions effectively, we would expect poor performance of targets prior to the takeover announcement. Therefore, we measure long-run pre-acquisition performance across

\section{Time to completion}

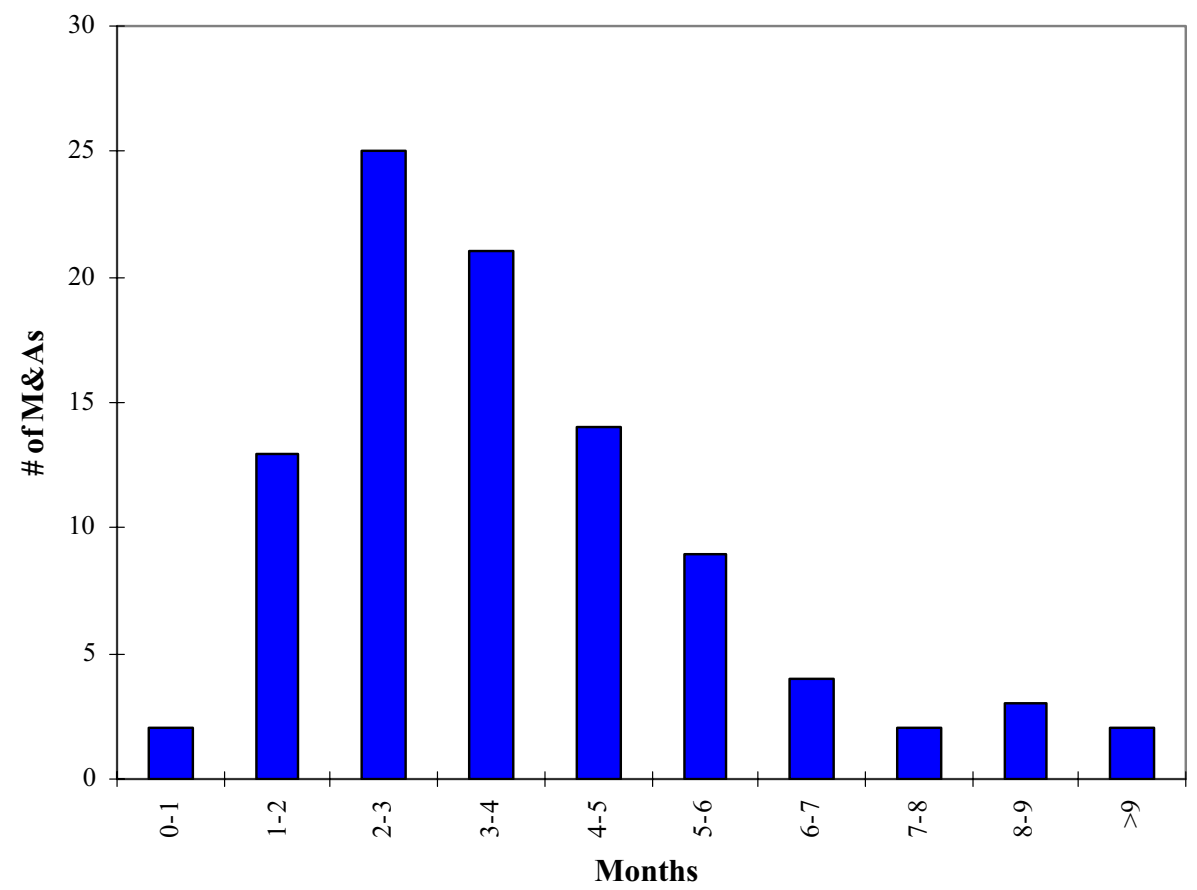

Fig. 1 Time to completion. This figure shows the average time to completion for takeovers in our sample. Completion time is calculated as number of months between the announcement date and the final acquisitions date of all target shares 
Table 3 Pre-acquisition performance targets

\begin{tabular}{|c|c|c|c|c|c|c|c|c|}
\hline \multicolumn{2}{|c|}{ Months around announcement } & \multicolumn{3}{|l|}{ Targets } & \multicolumn{3}{|c|}{ Control sample } & \multirow{2}{*}{$\frac{\text { Difference }}{\text { t-stat }}$} \\
\hline $\mathrm{t}_{1}$ & $t_{2}$ & CAR $(\%)$ & t-stat & $n$ & CAR $(\%)$ & t-stat & $n$ & \\
\hline \multicolumn{9}{|c|}{ Long-run pre-acquisition performance } \\
\hline-3 & -12 & -3.24 & $(-1.35)$ & 95 & 3.05 & $(1.67)^{\mathrm{a}}$ & 101 & $(2.08)^{\mathrm{b}}$ \\
\hline-3 & -24 & -0.46 & $(-0.12)$ & 87 & 6.54 & $(2.01)^{\mathrm{a}}$ & 98 & $(1.41)$ \\
\hline-3 & -36 & 6.62 & $(1.31)$ & 79 & 13.49 & $(3.31)^{\mathrm{b}}$ & 91 & $(1.06)$ \\
\hline-3 & -48 & 7.38 & $(1.52)$ & 68 & 16.86 & $(3.18)^{\mathrm{b}}$ & 83 & $(1.32)$ \\
\hline-3 & -60 & 11.49 & $(1.98)^{\mathrm{a}}$ & 63 & 22.22 & $(3.43)^{\mathrm{b}}$ & 77 & $(1.23)$ \\
\hline \multicolumn{9}{|c|}{ Performance around acquisition } \\
\hline-1 & & 1.24 & $(1.25)$ & 95 & 1.60 & $(1.84)^{\mathrm{a}}$ & 103 & $(-0.55)$ \\
\hline+1 & & 9.26 & $(10.04)^{\mathrm{b}}$ & 95 & -0.45 & $(-0.69)$ & 103 & $(8.63)^{\mathrm{b}}$ \\
\hline-1 & 1 & 10.50 & $(7.47)^{\mathrm{b}}$ & 95 & 1.82 & $(1.87)^{\mathrm{a}}$ & 103 & $(5.47)^{\mathrm{b}}$ \\
\hline
\end{tabular}

Long-run pre-acquisition performance of this table presents the pre-acquisition performance of targets and the control sample in the long run. CAR is the Cumulated Abnormal Return over the interval as stated in column 1, where abnormal returns are calculated using a market model based on Franks and Mayer (1996). Companies are only included in the analysis if they data was available for the specific time interval. The significance of the difference between performance of targets and the control sample is tested using a $t$ test assuming unequal variances. Performance around acquisition provides results on performance of targets and control sample around the bid announcement

${ }^{a}$ Indicates significance at the $10 \%$-level or less

${ }^{\mathrm{b}}$ Indicates significance at the $5 \%$-level or less

all targets using a market model, following Franks and Mayer (1996). ${ }^{7}$ The cumulative abnormal returns (CARs) are calculated for various time intervals, which all stop at month $t=-3$ to avoid noise due to information leakage in the months close to the announcement date. Furthermore, we match the sample of targets to the equivalent part of the control sample. Long-run pre-acquisition performance of Table 3 shows the results.

We find support for the inefficient management hypothesis in the short run, as abnormal performance of the targets is negative in the short run and significantly lower than performance of the control sample. Although targets underperform the control sample for all intervals in the long run, the significance disappears. Our results contrast previous literature (e.g. Agrawal and Jaffe 2003; Franks and Mayer 1996), as the underperformance of targets in the short run has not been documented before. To test for robustness and to get a better insight in this new finding, we make a distinction between performance of targets in REIT-REIT takeovers and performance of targets in non-REIT takeovers. We find that nonREIT targets exhibit significant underperformance in the short run and strongly varying performance in the long run. REIT targets underperform the control sample in the short run as well, but show a more stable performance over the

\footnotetext{
${ }^{7}$ As our sample includes targets from six countries, the use of a single market index would lead to estimation errors. Therefore, we match the market index to the origin of the target using GPR Local Indices (available on a monthly basis).
} 
long run. These results indicate that underperformance of real estate targets prior to takeovers does not depend on their legal structure. ${ }^{8}$

In Performance around acquisition of Table 3, we provide a first analysis of target performance around the bid announcement and find that abnormal returns over the announcement period are significantly positive, which is in line with existing literature. We will analyze post-announcement stock performance in more detail in "Wealth Effects Following Takeovers."

\section{Univariate Analyses}

After the first test of the inefficient management hypothesis, the next step is to investigate how targets and bidders differ from the control sample, by comparing financial characteristics, governance structure and portfolio characteristics. This preliminary analysis is performed by applying a sample $t$ test assuming equal variances, to compute whether the mean values of the variables differ significantly between the three groups. ${ }^{9}$

Regarding operating measures of performance, the results in Table 4 show that the return on assets and return on equity for targets are significantly lower as compared to bidders and the control sample. This again confirms the inefficient management hypothesis and expectations that acquiring firms are better able to generate revenue with their assets. Our results are in line with the previous analysis on stock performance of targets, but contrast existing literature, which does not document operating underperformance of targets (Agrawal and Walkling 1994; Song and Walkling 1993). Targets pay out less dividends than firms in the control sample, which might indicate that targets either have less cash available for distribution, for example due to bad performance, or they retain cash rather than paying out dividends, which would be line with Jensen's free cash flow theorem (1986). Furthermore, the variable on financial structure (leverage) indicates that targets are significantly more levered than non-targets and bidders. This result is in line with previous real estate research (Ambrose 1990; Campbell et al. 2001), and consistent with the synergy theory, which suggests that bidders prefer to acquire companies with a different financial structure. Moreover, the indebtness of targets combined with evidence on underperformance and low dividend yield, suggests that takeover targets are in a weak financial position.

The low beta for targets, bidders and the control sample suggests that real estate companies are less sensitive to market movements than firms in other sectors, with

\footnotetext{
${ }^{8}$ In our comparison of REIT vs non-REIT takeovers, we assume that potential differences are driven by the REIT-structure. However, differences between the two groups might as well be attributed to countryspecific characteristics, as the non-REIT sample is dominated by UK firms. The limited number of nonREITs in the USA restricts in-country comparison between REITs and non-REITs, but the recent adoption of the REIT structure in several Asian and European countries may enable future analysis on the impact of the REIT structure on corporate governance issues such as the market for corporate control.

${ }^{9}$ We stress that the means we compute are only meant to be suggestive, because we do not account for important differences between firms in the calculations. Therefore, some of the correlations might be spurious. Moreover, we do not make a distinction between REIT mergers and non-REIT mergers. We will deal with these issues in the logistic regression and assume the results presented next to be indicators of causal relationships between the variables and takeover probability.
} 
Table 4 Descriptive statistics of targets, bidders and the control sample

\begin{tabular}{|c|c|c|c|c|c|c|c|c|c|}
\hline \multirow[t]{2}{*}{ Variables } & \multicolumn{2}{|c|}{ Control group } & \multicolumn{2}{|l|}{ Targets } & \multicolumn{2}{|c|}{ Acquirers } & \multicolumn{3}{|l|}{ t-statistic } \\
\hline & Mean & SD & Mean & SD & Mean & SD & $\begin{array}{l}\text { Control } \\
\text { target }\end{array}$ & $\begin{array}{l}\text { Target } \\
\text { acquirer }\end{array}$ & $\begin{array}{l}\text { Control } \\
\text { acquirer }\end{array}$ \\
\hline \multicolumn{10}{|l|}{ Financial characteristics } \\
\hline Stock performance & 3.05 & 18.25 & -3.24 & 22.48 & 4.34 & 10.76 & $2.08^{\mathrm{a}}$ & $-2.61^{\mathrm{a}}$ & -0.53 \\
\hline Return on assets & 7.06 & 2.93 & 6.01 & 3.05 & 7.69 & 3.83 & $2.41^{\mathrm{a}}$ & $-2.60^{\mathrm{a}}$ & 1.00 \\
\hline Return on equity & 10.27 & 7.89 & 7.66 & 8.83 & 10.71 & 6.87 & $2.11^{\mathrm{a}}$ & $-2.21^{\mathrm{a}}$ & -0.34 \\
\hline $\begin{array}{r}\text { Funds from } \\
\text { operations }\end{array}$ & 0.05 & 0.03 & 0.04 & 0.03 & 0.05 & 0.06 & $2.76^{\mathrm{a}}$ & -0.71 & 0.59 \\
\hline EPS growth & 0.31 & 0.70 & 0.27 & 0.66 & 0.39 & 0.65 & 0.38 & 0.94 & -0.59 \\
\hline Dividend yield & 7.29 & 4.18 & 5.40 & 3.43 & 5.89 & 3.16 & $3.44^{\mathrm{a}}$ & -0.85 & $2.29^{\mathrm{a}}$ \\
\hline $\begin{array}{l}\text { Selling } \\
\text { expenditures }\end{array}$ & 1.17 & 0.02 & 1.15 & 0.02 & 1.11 & 0.02 & 0.04 & 0.12 & 0.18 \\
\hline Cash holdings & 3.60 & 4.80 & 2.75 & 3.86 & 2.88 & 4.88 & 1.34 & -0.16 & 0.83 \\
\hline Leverage & 1.13 & 0.76 & 1.26 & 1.20 & 0.77 & 0.77 & -0.88 & $2.91^{\mathrm{a}}$ & $2.68^{\mathrm{a}}$ \\
\hline Beta & 0.45 & 0.33 & 0.39 & 0.20 & 0.29 & 0.21 & 1.42 & $2.67^{\mathrm{a}}$ & $3.51^{\mathrm{a}}$ \\
\hline Market value $(\$ M)$ & 552.85 & 567.38 & 553.72 & 736.21 & 1599.25 & 1952.61 & 1.17 & $-4.63^{\mathrm{a}}$ & $-3.94^{\mathrm{a}}$ \\
\hline $\begin{array}{l}\text { Market-to-book } \\
\text { value }\end{array}$ & 1.24 & 0.92 & 0.97 & 1.08 & 1.10 & 0.65 & $1.90^{\mathrm{b}}$ & -0.88 & 1.14 \\
\hline \multicolumn{10}{|c|}{ Governance characteristics } \\
\hline Blockholdings & 0.29 & 0.18 & 0.36 & 0.20 & 0.31 & 0.21 & $-2.37^{\mathrm{a}}$ & 1.35 & -0.46 \\
\hline Insider holdings & 0.28 & 1.42 & 0.09 & 0.14 & 0.11 & 0.17 & 1.35 & -0.62 & 1.20 \\
\hline$\%$ non-executives & 0.48 & 0.13 & 0.41 & 0.27 & 0.60 & 0.19 & $1.86^{\mathrm{b}}$ & $-3.87^{\mathrm{a}}$ & $-3.15^{\mathrm{a}}$ \\
\hline $\begin{array}{l}\text { In-house } \\
\text { management }\end{array}$ & 0.88 & 0.32 & 0.78 & 0.42 & 0.88 & 0.33 & $1.96^{\mathrm{a}}$ & $1.65^{\mathrm{b}}$ & 0.02 \\
\hline Liquidity & 0.55 & 1.34 & 0.99 & 2.38 & 0.51 & 0.60 & -1.59 & $1.85^{\mathrm{b}}$ & 0.25 \\
\hline \multicolumn{10}{|l|}{ Portfolio characteristics } \\
\hline Office & 0.10 & 0.30 & 0.16 & 0.37 & 0.20 & 0.40 & -0.57 & -1.28 & -1.56 \\
\hline Retail & 0.22 & 0.42 & 0.26 & 0.44 & 0.47 & 0.50 & $-2.47^{\mathrm{a}}$ & $-3.02^{\mathrm{a}}$ & -1.28 \\
\hline Residential & 0.17 & 0.38 & 0.08 & 0.28 & 0.10 & 0.30 & $1.92^{\mathrm{b}}$ & -0.27 & 1.36 \\
\hline Diversified & 0.26 & 0.44 & 0.36 & 0.48 & 0.24 & 0.43 & -1.45 & 1.58 & 0.36 \\
\hline International & 0.09 & 0.28 & 0.12 & 0.32 & 0.22 & 0.42 & -0.66 & 1.49 & $1.99^{\mathrm{a}}$ \\
\hline Development & 0.14 & 0.34 & 0.74 & 0.44 & 0.18 & 0.39 & $-10.60^{\mathrm{a}}$ & $7.95^{\mathrm{a}}$ & -0.64 \\
\hline
\end{tabular}

In this table, descriptive statistics and the preliminary results of the comparison between targets, acquirers and control group are provided. Absolute values of variables are reported in nominal dollars. The last columns show the t-statistics of the paired sample $t$ test, assuming unequal variances. The definitions of all variables are provided in Appendix

${ }^{a}$ Indicates significance at the $5 \%$-level or less

${ }^{\mathrm{b}}$ Indicates significance at the $10 \%$-level or less

bidding firms even less risky than target firms. Furthermore, the average size of bidders is almost three times as large as the average size of the targets and control firms. This is in line with expectations that large companies have more market power to engage in acquisitions and are better able to integrate acquired assets in their operations. We compare our average target size $(\$ 554 \mathrm{M})$ to other studies and find that targets in our sample are slightly smaller as compared to both other real estate studies (Campbell et al. 2001: $\$ 650 \mathrm{M}$ ) and more general takeover studies (Mikkelson and Partch 1989: \$787 M; Song and Walkling 1993: \$727 M). This is probably due to the inclusion of European companies in our sample, which generally have a smaller size. Finally, the low market-to-book value frequently observed for 
listed property companies is again documented in our descriptive statistics, which indicate that real estate targets trade at a small discount on average.

Besides financial characteristics, we include control variables on corporate governance characteristics as the lack of hostile takeovers in the real estate sector may enhance the need for alternative governance mechanisms (Whidbee 1997). First, the percentage of shares in the hands of the three largest shareholders is significantly higher for targets, which is in line with Shivdasani (1993), who finds that large shareholders play an active role as a monitoring mechanism by facilitating takeovers. Targets have a significantly lower percentage of non-executive directors on the board as compared to non-targets, which provides support for the hypothesis that target firms have a weaker internal governance structure. Finally, the results show that targets are more often externally managed than control firms and bidders. This is in line with Ambrose and Linneman (2001), who find that externally managed REITs are less competitive than internally managed REITs.

Lastly, the descriptive statistics show that portfolio characteristics differ significantly between targets, bidders and the control sample. Bidders are more often international companies than targets or control firms. This suggests that the local knowledge that is required for cross-border investments makes the acquisition of a foreign company a useful tool. With respect to the portfolio of bidders and targets, the results show that takeover targets are mostly real estate companies with a diversified portfolio, involved in development activities, which is in line with expectations, as diversification of operations rather than focussing on a single asset or activity is often associated with underperformance. Acquirers seem to have an investment focus on retail and office property.

\section{Multivariate Results}

In order to estimate the joint impact of the previously discussed variables on the probability of a takeover attempt, we use a multinomial logistic regression model. We follow a broad stream of literature by comparing characteristics of acquired firms to a sample of control firms, and moreover, we extend the traditional methodology (Ambrose 1990; Barnes 1999; Dietrich and Sorensen 1984; Palepu 1986) by including bidders. To solve the problem of multicollinearity, we perform a stepwise regression of correlated variables and use the residuals in the multinomial analysis. To interpret the results correctly, we should point out that the focus of interest of our study is the significance of the estimated coefficients of the variables and not the predictive ability of the model (Palepu 1986). Therefore, the coefficients do not have economic significance except for their sign.

Table 5 presents the logistic regression results. We confirm previous findings that, in line with the inefficient management hypothesis, weak operating and stock performance of real estate companies are positively related to takeover likelihood. The significantly negative coefficients for both operating and stock performance are not consistently documented in the corporate finance literature. For bidders, size is positively related to the probability of being an acquirer, indicating that large firms may have efficiencies and resources that make them more likely to acquire other firms (Trahan 1993).

To check for robustness of the results and to account for the different legal structure of REITs compared to non-REITs, we repeat the analysis for REIT-REIT 
Table 5 Results multinomial logistic regression

\begin{tabular}{|c|c|c|c|c|}
\hline \multirow[t]{2}{*}{ Intercept } & \multicolumn{2}{|l|}{ Targets } & \multicolumn{2}{|c|}{ Acquirers } \\
\hline & 1.81 & $(1.10)$ & -6.36 & $(-3.02)^{\mathrm{a}}$ \\
\hline \multicolumn{5}{|l|}{ Financial characteristics } \\
\hline Market value (log) & -0.03 & $(-0.19)$ & 0.65 & $(3.01)^{\mathrm{a}}$ \\
\hline Stock return & -3.12 & $(-2.77)^{\mathrm{a}}$ & 1.58 & $(0.97)$ \\
\hline Return on assets & -0.16 & $(-2.12)^{\mathrm{a}}$ & 0.07 & $(0.92)$ \\
\hline Cash holdings & -0.09 & $(-1.59)$ & -0.04 & $(-0.72)$ \\
\hline Leverage & -0.04 & $(-0.15)$ & -0.56 & $(-1.70)^{\mathrm{b}}$ \\
\hline Beta & -2.98 & $(-2.77)^{\mathrm{a}}$ & -2.63 & $(-2.02)^{\mathrm{a}}$ \\
\hline \multicolumn{5}{|c|}{ Governance characteristics } \\
\hline$\%$ non-executives & -0.94 & $(-0.85)$ & 3.93 & $(2.66)^{\mathrm{a}}$ \\
\hline Insider holdings & -1.40 & $(-2.55)^{\mathrm{a}}$ & 0.12 & $(0.18)$ \\
\hline In-house management & -1.97 & $(-1.57)$ & 0.01 & $(0.04)$ \\
\hline Blockholdings & 2.82 & $(2.45)^{\mathrm{a}}$ & -0.61 & $(-0.51)$ \\
\hline Liquidity & 0.09 & $(0.69)$ & -0.01 & $(-0.04)$ \\
\hline \multicolumn{5}{|l|}{ Portfolio characteristics } \\
\hline Diversified & 0.07 & $(0.12)$ & 0.92 & $(1.37)$ \\
\hline Office & -0.01 & $(-0.02)$ & 1.57 & $(2.00)^{\mathrm{a}}$ \\
\hline Retail & -0.63 & $(-1.08)$ & 2.19 & $(3.48)^{\mathrm{a}}$ \\
\hline Development & 3.50 & $(6.98)^{\mathrm{a}}$ & 0.03 & $(0.04)$ \\
\hline Market-to-book value & -0.63 & $(-2.21)^{\mathrm{a}}$ & -0.24 & $(-0.70)$ \\
\hline Model chi-square & 208.11 & & & \\
\hline Pseudo $R$-square & 0.40 & & & \\
\hline$N$ & 248 & & & \\
\hline
\end{tabular}

This table shows the results for the multinomial logistic regression. Column 2 includes the regression results for targets, whereas column 3 includes the regression results for acquirers. The pseudo $R$-square is the analogue of the $R 2$ in the normal linear regression model. The chi-square tests the null hypothesis that all parameters in the model are zero and is the equivalent of the $F$ test in the normal regression model. The null-hypothesis is rejected in all models

${ }^{a}$ Indicates significance at the $5 \%$-level or less

${ }^{\mathrm{b}}$ Indicates significance at the $10 \%$-level or less

takeovers and non-REIT takeovers separately. ${ }^{10}$ In general, our findings are similar to the results reported in Table 5, and most importantly, the repeated analysis confirms that the financial performance of targets in both samples is significantly negatively related to the takeover probability. Therefore, we confirm our previous findings that the inefficient management holds for REIT takeovers as well as nonREIT takeovers. One main difference is that low cash holdings lead to an increased takeover probability in REIT takeovers, which is not documented for non-REIT mergers. As REITs face the obligatory payout of cash flows, cash-trapped firms cannot easily solve financial problems and are therefore, combined with poor performance, more vulnerable to takeovers.

The signs of the corporate governance variables mainly confirm the results of the univariate analysis. For targets, the variable on insider holdings is now significantly negative, which suggests that increased managerial stockholdings deter takeovers. This might indicate that large inside shareholdings entrench managers rather than reduce the agency gap (North 2001; Song and Walkling

\footnotetext{
${ }^{10}$ For reasons of space, results are not reported, but these are available upon request. 
1993). This adds to earlier evidence by Ghosh and Sirmans (2003), who partially explain the absence of hostile takeovers for REITs by the negative effects of larger insider shareholdings. The presence of large blockholders increases the likelihood of becoming a takeover target, which suggests that large shareholders are effective monitoring mechanisms (North 2001; Shivdasani 1993). Furthermore, we find that property companies with an independent board have an increased likelihood to be bidders in takeovers.

We repeat the multinomial regression analysis for REIT takeovers and nonREIT takeovers separately and find that the relationship between governance and takeover likelihood is different for REIT targets as compared to non-REIT targets, whereas for bidders this relationship is similar for REITs and non-REITs. First, we documented previously that the presence of large blockholders increases the takeover likelihood for targets, but this result seems to be driven by the REITs in our sample. This is counterintuitive, as it is often argued that the 5-50 rule imposed on REITs limits the creation of large shareholders and thus hinders hostile takeovers (Ghosh and Sirmans 2003). However, our result is in line with Ling and Ryngaert (1997), who state that larger blocks of shares held by outsiders might facilitate takeovers, both because of lower transaction costs and by reducing free-rider problems by small shareholders. Second, we find evidence for REITs that a relatively low number of non-executives on the board increase the takeover likelihood, which is consistent with Weir (1997) and North (2001). They document that non-executives are only weakly represented on the boards of targets, potentially leading to weaker boards and thus less efficient monitoring. Third, the negative sign for insider shareholdings is documented for REIT takeovers as well as non-REITs takeovers.

Finally, the results on portfolio characteristics reveal that targets and bidders are only slightly different from the control sample. Property companies with operations involving development activities face an increased takeover likelihood. Furthermore, the coefficient on the market-to-book value is significantly negative for targets. This result is not surprising and indicates that the market-tobook value is a driver of takeovers within the real estate sector, even though there may be large cross-country differences and variations over time. Real estate companies with a focus on retail and office property have an increased likelihood to be bidders, which is in line with anecdotal evidence that retail mergers are prevailing in the USA.

We again compare between REIT takeovers and non-REIT takeovers and find that targets in non-REIT mergers have a significantly negative coefficient for the market-to-book value, whereas this result does not hold for REITs. This difference might be due to the transparency of REITs as compared to nonREITs, which leads to less information asymmetry between firms and shareholders. Therefore, the market is able to price REITs more accurately than non-REITs.

The analysis of the characteristics of bidders and targets in real estate takeovers has revealed interesting results, which have not been documented for the real estate sector before. Although the consistently documented absence of hostile takeovers in the real estate sector lead to expectations that the market for corporate control does not work properly for the property sector, our results confirm the inefficient 
management hypothesis: targets in the real estate takeover market are underperforming firms. This suggests that the market for corporate control is effective in the real estate sector, even without the threat of hostile takeovers.

\section{Wealth Effects Following Takeovers}

The former section provided insight in the underlying drivers of real estate takeovers, thereby focussing on pre-acquisition characteristics of targets and bidders to get an insight in the effectiveness of the market for corporate control in the real estate sector. This section elaborates on the previous section by studying the wealth effects surrounding the announcement of a takeover bid. Following the inefficient management hypothesis, the takeover of underperforming targets should lead to positive wealth effects for both targets and bidders. This section will start with a short discussion of methodological issues; hereafter the event study results are presented.

\section{Methodology}

The impact of acquisitions on the shareholder wealth of acquirers and targets can be determined using several event study methods, among which the OLS market model and the comparison period approach (Brown and Warner 1980). Although the OLS market model has been used in comparable studies, for example Chang (1998) and Campbell et al. (2001), our sample seems to be better suited to the comparison period approach. The acquisitions in our sample take place in several different countries, which leads to difficulties in using a single market index. Moreover, the use of several different market indices for the various markets leads to an estimation error, because the disturbance term is affected by other factors in addition to the announcements under study, such as macro-economic movements, which might differ significantly across countries. Another issue is the relative illiquidity of a substantial part of the stocks in our sample in comparison to the matched market index, leading to the estimation of unreliable market factors. Finally, the choice for the comparison period method is justified by Brown and Warner (1980), who argue that the comparison period returns approach is at least as powerful as and often even more powerful as market adjusted approaches.

We estimate the mean return $\left(\mu_{i t}\right)$ of each security $i$ for a comparison period running from day -120 through day -20 prior to the day of the first public announcement $(t=0)$. The event period disturbance term can than be estimated by subtracting $\mu_{i t}$ from the realized return $R_{i t}$. We measure announcement-period returns from day -1 through day +1 , resulting in a cumulative abnormal return CAR:

$$
\mathrm{CAR}=\sum_{-1}^{+1} \bar{\varepsilon}_{t}
$$

where

$$
\bar{\varepsilon}_{t}=\left[(1 / N) \sum_{i=1}^{N} \varepsilon_{i t}\right]
$$




$$
\begin{gathered}
\varepsilon_{i t}=R_{i t}-\mu_{i t} \\
\mu_{i t}=\left[(1 / 100) \sum_{-120}^{-21} R_{i t}\right]
\end{gathered}
$$

We assume that the portfolio daily returns are normally distributed and stationary, which allows us to use a significance test for the null hypothesis of equality of event period and comparison period means based on the methodology of Mood-Graybill-Boes (1974).

\section{Results}

Table 6 shows the average abnormal returns for bidding and target firms, subject to the method of payment and the identity of the merger (REIT-REIT or non-REIT mergers). Target firms provides the two and three day CARs for acquisition targets, which are significantly positive $(8.66 \%)$ for the sample as a whole. The wealth effects we find are substantially higher than results reported by Campbell et al. (2001) and McIntosh et al. (1989), although these authors use a market model and do not distinguish between stock and cash payments. Compared to more general corporate finance studies, our results are lower than the 10 to $23 \%$ as found by for example Jensen and Ruback (1983) and Servaes (1991). The lower level of our results may well be caused by the homogeneity of assets of real estate companies, which decreases the potential for synergy profits emerging from merged operations.

Studying the abnormal returns to targets in more detail, we find that targets receiving a bid from a private firm receive higher abnormal returns in comparison to targets receiving a public bid. This might be due to the fact that the main part of private bids in our sample consists of MBOs: as the management of a company has superior knowledge of the firm, they will be best able to establish the exact value of the company and to create value following a takeover. Furthermore, we find that the scope of wealth effects for targets in REIT takeovers is different compared to wealth effects for targets in non-REIT takeovers. CARs in REIT takeovers financed with stock are quite similar to previous findings in the real estate literature, for example, Campbell et al. (2001) document a three day CAR of 3.2\%. However, we document CARs for cash bids that are substantially higher. This is in line with academic evidence that cash bids lead to higher CARs than stock bids, due to signalling effects (Myers and Majluf 1984). However, this result has not been documented before, because previous comparable studies included stock-financed REIT takeovers only.

Finally, stock bids in non-REIT takeovers lead to insignificant wealth effects. On the one hand, the low number of stock bids in non-REIT mergers might be a driver of this result, but it might as well be an indicator for the aversion of shareholders against stock as a method of payment. This result is contrasting the significant 
Table 6 Shareholder wealth effects for targets and bidders following takeovers

\begin{tabular}{lcrr}
\hline & Number & CAR & CAR \\
\cline { 3 - 4 } & & $t[-1,0,1]$ & $t[0,+1]$ \\
\hline Target firms & & & \\
All bids & 95 & $8.66 \%(3.23)^{\mathrm{a}}$ & $8.21 \%(6.76)^{\mathrm{a}}$ \\
Cash bids & 63 & $10.86 \%(3.27)^{\mathrm{a}}$ & $10.46 \%(7.21)^{\mathrm{a}}$ \\
Stock/mixed bids & 32 & $4.35 \%(1.92)^{\mathrm{b}}$ & $3.79 \%(3.14)^{\mathrm{a}}$ \\
Public bidder & 51 & $6.95 \%(3.00)^{\mathrm{a}}$ & $6.72 \%(6.38)^{\mathrm{a}}$ \\
Private bidder & 44 & $10.10 \%(3.04)^{\mathrm{a}}$ & $10.24 \%(6.02)^{\mathrm{a}}$ \\
REIT takeovers & 43 & $6.69 \%(3.25)^{\mathrm{a}}$ & $6.92 \%(6.77)^{\mathrm{a}}$ \\
Cash & 15 & $10.19 \%(3.06)^{\mathrm{a}}$ & $10.39 \%(7.67)^{\mathrm{a}}$ \\
Stock/mixed & 28 & $4.80 \%(2.14)^{\mathrm{a}}$ & $4.21 \%(3.66)^{\mathrm{a}}$ \\
Non-REIT takeover & 37 & $10.15 \%(3.05)^{\mathrm{a}}$ & $10.27 \%(6.02)^{\mathrm{a}}$ \\
Cash bids & 33 & $11.33 \%(3.12)^{\mathrm{a}}$ & $10.27 \%(6.27)^{\mathrm{a}}$ \\
Stock/mixed bids & 4 & $0.06 \%(0.37)$ & $-0.05 \%(-0.01)$ \\
Bidding firms & & & \\
All offers & 51 & $0.37 \%(0.39)$ & $0.48 \%(0.86)$ \\
Cash offers & 20 & $0.33 \%(0.28)$ & $0.34(0.42)$ \\
Stock offers & 31 & $0.48 \%(0.22)$ & $0.80 \%(0.58)$ \\
REIT takeovers & 43 & $0.27 \%(0.23)$ & $0.77 \%(0.50)$ \\
Cash & 14 & $0.14 \%(0.35)$ & $0.89 \%(0.64)$ \\
Stock & 29 & $0.23 \%(0.19)$ & $0.31 \%(0.44)$ \\
Non-REIT takeovers & 8 & $1.51 \%(0.57)$ & $1.40 \%(1.07)$ \\
\hline
\end{tabular}

This table presents the results of the event study on the wealth effects following takeovers in the real estate sector. Target firms reports the average 3-day and 2-day cumulative abnormal return to targets, thereby distinguishing cash bids and bids which are (at least partially) stock-financed. Moreover, we make a distinction between REIT-to-REIT takeovers and takeovers involving non-REITs. Bidding firms presents the event study results for bidders. Tstatistics are based on a conventional significance test for the null hypothesis of equality of event period and comparison period means, based on methodology of MoodGraybill-Boes (1974, p. 435)

${ }^{a}$ Indicates significance at the $5 \%$-level or less

${ }^{\mathrm{b}}$ Indicates significance at the $10 \%$-level or less

wealth effects following stock-financed REIT takeovers. The latter might well be due to the fact that REITs are restricted in retaining cash, which leaves managers nothing but stock as a method of payment in takeovers.

Bidding firms presents the shareholder wealth effects accruing to the bidders and shows that cash bidders earn an insignificant $0.33 \%$ abnormal return. Stock bidders earn a $0.48 \%$ return, but this result is insignificant as well. The performance of the bidders in our sample is lower than the 6.37\% CAR documented by Allen and Sirmans (1987), but is slightly better than results found by Campbell et al. (2001), who document a $-0.6 \%$ abnormal return. Again, these comparisons should be interpreted with care due to the difference in methodology. Our results confirm that takeovers in the listed real estate sector lead more favourable stock market reactions for bidders compared to findings in other sectors: Asquith et al. (1983), Travlos (1987), Hyun (1993) and Chang (1998) all find significantly negative bidder wealth effects for both stock and cash offers.

The findings of our event study show that takeovers in the real estate sector lead to significantly positive aggregate wealth effects, which confirms the inefficient management hypothesis. The results are generally in line with the real estate 
takeover literature, but we contribute to existing studies by including wealth effects following mergers of non-REITs. With respect to these mergers, we document larger CARs as compared to REIT mergers. Our findings differ from the finance literature, where larger gains to targets and larger losses to bidders have been documented. Our findings of small rather than large fluctuations in stock prices of targets and bidders seems to be justified by the homogeneity of operations in real estate mergers, which does not allow for large value-creating synergies.

\section{Conclusions and Discussion}

The different aspects of the market for corporate control have been studied extensively in the corporate finance literature and to some extent in the real estate literature. This paper adds to existing evidence by investigating the inefficient management hypothesis for the real estate sector during the most recent takeover wave, using an international sample. The real estate sector provides an interesting and increasingly important field of research, both because of the trend in institutionalization of the real estate sector and because of its distinct governance structure. Moreover, the documented lack of hostile takeovers for the real estate sector leads to the question whether the market for corporate control functions effectively in the property sector.

Our results indicate that, although the market for corporate control in the real estate sector does not discipline managers via hostile takeovers, poor firm performance is a predominant motive for takeovers. This confirms the inefficient management hypothesis and thereby adds new evidence to the existing real estate finance literature. However, the question why hostile takeovers do not take place in the real estate sector still remains unanswered. We suggest three explanations for this.

First, hostile takeovers do probably not create more value than friendly takeovers. The lack of hostile takeovers in the real estate sector does not allow for empirical testing of this hypothesis, but Schwert (2000) indeed finds that hostile bids have lower success rates and on average pay a higher premium to target shareholders.

Second, the most important characteristic of hostile takeovers is the information asymmetry that arises when a hostile bid is made. Despite this information asymmetry, managers are often willing to take the risk of overpaying because this premium will be offset by growth in future revenues. The information problem is relatively small in the real estate sector as the valuation of operations (i.e. a property portfolio) is rather straightforward. Therefore, we would expect a large number of hostile takeovers. However, in the real estate sector the growth of revenues is rather predictable and stable, so although the information asymmetry is less of a problem in hostile takeovers, it will take considerable time to regain possible overpayments in the real estate sector, making it an unattractive alternative to friendly takeovers.

Our third hypothesis is that the REIT structure increases transparency, which is so beneficial to corporate governance that it makes the market for corporate control less important as a governance mechanism. Or inversely, the REIT structure may decrease transparency due to dispersed stock ownership, thereby deterring hostile takeovers (Ghosh and Sirmans 2003). However, our sample shows that hostile takeovers do not take place in real estate markets without the REIT structure either, which suggests that the operations of real estate companies, whether they have a 
REIT-status or not, are relatively transparent. This reduces the need for an active market for corporate control by means of hostile takeovers.

The latter part of our study shows that the real estate takeover market does not only differ from other sectors with respect to hostile takeovers, but wealth effects surrounding takeovers are different as well. We document abnormal returns of a smaller scope as compared to wealth effects found in studies for other sectors, which is consistent with previous studies on takeovers in the real estate sector (Allen and Sirmans 1987; Campbell et al. 2001). The smaller scope of the wealth effects might be justified by the homogeneity in operations of real estate companies, which does not allow for large synergy benefits following mergers.

Concluding, we can state that our findings indicate that the lack of hostile takeovers in the real estate sector does not by definition lead to a weak market for corporate control, as underperforming targets face an increased takeover likelihood. However, the exact reason for the lack of hostile takeovers is still hard to establish. The illiquidity of some of the smaller international real estate markets hinders a complete international study of the real estate takeover market and the use of a market model to establish shareholder wealth effects, thereby opening possibilities for future research. Furthermore, we investigate the takeover market as an important external governance mechanism, but apart from studying how governance structures differ between targets and bidders, we do not address interaction between external governance, internal governance and equity prices, which have recently been shown to be interrelated (Cremers and Nair 2005). This might be an interesting venue for corporate governance research in real estate, because of the experimental laboratory offered by REITs and its distinct impact on corporate governance mechanisms. Finally, we study wealth effects following takeovers in the short run only. A longrun perspective could possible provide better insights in the wealth effect differences between takeovers in the real estate sector and results documented for takeovers in other sectors.

Acknowledgement We acknowledge the helpful comments of Martin Hoesli, Simon Stevenson, Tony Key and an anonymous referee, as well as seminar and conference participants at Cass Business School, Université de Liège, HEC Geneva and the 2005 ERES Conference, Dublin. We also thank Jeroen Beimer (Global Property Research) for his efforts in data collection. All remaining errors are ours.

\section{Appendix}

Table 7 Explanatory variables

\begin{tabular}{llll}
\hline Variable & Definition & Source & $\begin{array}{l}\text { Based on } \\
\text { item }\end{array}$ \\
\hline Financial characteristics & & \\
\multicolumn{2}{l}{ Stock return } & Monthly stock return & Datastream RI \\
Return on assets & Net income divided by total assets & Worldscope WC08326 \\
Return on equity & Net income divided by total equity & Worldscope WC08301 \\
Growth in EPS & Earnings per share growth during 3 & Datastream EPS
\end{tabular}


Table 7 (continued)

\begin{tabular}{|c|c|c|c|}
\hline Variable & Definition & Source & $\begin{array}{l}\text { Based on } \\
\text { item }\end{array}$ \\
\hline $\begin{array}{l}\text { Funds from } \\
\text { operation to assets }\end{array}$ & $\begin{array}{l}\text { Sum of earnings, depreciation and } \\
\text { amortization divided by total assets }\end{array}$ & Worldscope & WC04201 \\
\hline Selling expenditures & $\begin{array}{l}\text { Sum of selling, general and administrative } \\
\text { expenses divided by sales }\end{array}$ & Worldscope & WC01101 \\
\hline Beta & Variance in stock return & Worldscope & WC09802 \\
\hline Debt-to-equity & Total debt divided by common equity & Worldscope & WC03255 \\
\hline Cash holdings & Cash and marketable securities divided by total assets & Worldscope & WC02001 \\
\hline Dividend yield & Dividend per share as a percentage of the share price & Datastream & DY \\
\hline Market value & $\begin{array}{l}\text { Share price multiplied by the number of } \\
\text { ordinary shares outstanding }\end{array}$ & Datastream & MV \\
\hline $\begin{array}{l}\text { Market-to-book } \\
\text { ratio }\end{array}$ & $\begin{array}{l}\text { Market value of common equity divided by balance } \\
\text { sheet value of common equity }\end{array}$ & Datastream & MTBV \\
\hline \multicolumn{4}{|c|}{ Governance characteristics } \\
\hline \# of non-executives & $\%$ of non-executive directors on the board & $\begin{array}{l}\text { Annual } \\
\text { reports }\end{array}$ & \\
\hline Insider holdings & $\%$ of shares held by directors of the company & $\begin{array}{l}\text { Annual } \\
\text { reports }\end{array}$ & \\
\hline $\begin{array}{l}\text { Ownership } \\
\text { concentration }\end{array}$ & $\%$ of shares held by the 3 largest investors & $\begin{array}{l}\text { Annual } \\
\text { reports }\end{array}$ & \\
\hline $\begin{array}{l}\text { External } \\
\text { management }\end{array}$ & Company managed by an external entity & $\begin{array}{l}\text { Annual } \\
\text { reports }\end{array}$ & \\
\hline Liquidity & \# of shares traded per day divided by market value & Worldscope & WC08011 \\
\hline \multicolumn{4}{|l|}{ Portfolio characteristics } \\
\hline Property type & Sector of investment & $\begin{array}{l}\text { Annual } \\
\text { reports }\end{array}$ & \\
\hline $\begin{array}{l}\text { International } \\
\text { investments }\end{array}$ & Cross-border investments (at least $25 \%$ ) & $\begin{array}{l}\text { Annual } \\
\text { reports }\end{array}$ & \\
\hline Diversification & Company invests in more than one asset (at least $25 \%$ ) & $\begin{array}{l}\text { Annual } \\
\text { reports }\end{array}$ & \\
\hline Development & Company has development and/or construction activities & $\begin{array}{l}\text { Annual } \\
\text { reports }\end{array}$ & \\
\hline
\end{tabular}

This table provides an overview of the explanatory variables exploited in the analysis of takeovers, including a short description. Source and item number are provided in columns three and four. All absolute values are expressed in nominal dollars

\section{References}

Agrawal, A., \& Jaffe, J. F. (2003). Do takeover targets underperform? Evidence from operating and stock returns. Journal of Financial and Quantitative Analysis, 38, 721-746.

Agrawal, A., \& Walkling, R. A. (1994). Executive careers and compensation surrounding takeover bids. Journal of Finance, 49, 985-1014.

Allen, P. R., \& Sirmans, C. F. (1987). An analysis of gains to acquiring firm's shareholders: The special case of REITs. Journal of Financial Economics, 18, 175-184.

Ambrose, B. W. (1990). Corporate real estate's impact on the takeover market. Journal of Real Estate Finance and Economics, 3, 307-322.

Ambrose, B. W., \& Linneman, P. (2001). REIT organizational structure and operating characteristics. Journal of Real Estate Research, 21, 141-162.

Ambrose, B. W., \& Megginson, W. L. (1992). The role of asset structure, ownership structure, and takeover defenses in determining acquisition likelihood. Journal of Financial \& Quantitative Analysis, 27, 575-589. 
Asquith, P., Bruner, R. F., \& Mullins, D. W. (1983). The gains to bidding firms from mergers. Journal of Financial Economics, 11, 121-139.

Asquith, P., \& Kim, E. H. (1982). The impact of merger bids on the participating firm's security holders. Journal of Finance, 37, 1209-1228.

Barber, B. M., Palmer, D., \& Wallace, J. (1994). Determinants of conglomerate and predatory acquisitions during the 1960s. Journal of Finance, 49, 1047-1048.

Barnes, P. (1999). Predicting UK takeover targets: Some methodological issues and an empirical study. Review of Quantitative Finance and Accounting, 12, 282-302.

Berger, P. G., \& Ofek, E. (1996). Bustup takeovers of value-destroying diversified firms. Journal of Finance, 51, 1175-1200.

Brounen, D., \& ter Laak, M. (2005). Understanding the discount: Evidence from European property shares. Journal of Real Estate Portfolio Management, 11, 241-251.

Brown, S. J., \& Warner, J. B. (1980). Measuring security price performance. Journal of Financial Economics, 8, 205-258.

Campbell, R. D. (2002). Shareholder wealth effects in equity REIT restructuring transactions: Sell-offs, mergers and joint ventures. Journal of Real Estate Literature, 10, 205-222.

Campbell, R., Ghosh, C., \& Sirmans, C. F. (2001). The information content of method of payment in mergers: Evidence from real estate investment trusts (REITs). Real Estate Economics, 29, 360-387.

Chang, S. (1998). Takeovers of privately held targets, methods of payment, and bidder returns. Journal of Finance, 53, 773-784.

Cremers, M., \& Nair, V. B. (2005). Governance mechanisms and equity prices. Journal of Finance, 60, 2859-2894.

Dietrich, J. K., \& Sorensen, E. (1984). An application of logit analysis to prediction of merger targets. Journal of Business Research, 12, 393-402.

Dodd, P. (1980). Merger proposals, management discretion and stockholder wealth. Journal of Financial Economics, 8, 105-138.

Dodd, P., \& Ruback, R. (1977). Tender offers and stockholder returns. Journal of Financial Economics, 5, 351-373.

Eichholtz, P. M. A., Koedijk, K., \& Schweitzer, M. (2001). Global property investment and the costs of international diversification. Journal of International Money \& Finance, 20, 349-366.

Ellert, J. C. (1976). Mergers, antitrust law enforcement and stockholder returns. Journal of Finance, 31, $715-732$.

Franks, J., \& Mayer, C. (1996). Hostile takeovers and the correction of managerial failure. Journal of Financial Economics, 40, 163-181.

Franks, J., Harris, R. S., \& Mayer, C. (1988). Means of payment in takeovers: results for the United Kingdom and the United States. In: A. Auerbach, ed., Corporate takeovers: causes and consequences, National Bureau of Economic Research, University of Chicago Press.

Ghosh, C., \& Sirmans, C. F. (2003). Board independence, ownership structure and performance: Evidence from real estate investment trusts. Journal of Real Estate Finance \& Economics, 26, 287-318.

Graham, J. R., Lemmon, M. L., \& Wolf, J. G. (2002). Does corporate diversification destroy value? Journal of Finance, 57, 695-720.

Hyun, S. (1993). The effects of overpayment and form of financing on bidder returns in mergers and tender offers. Journal of Financial Research, 16, 351-365.

Jensen, M. C. (1986). Agency costs of free cash flow, corporate finance, and takeovers. American Economic Review, 76, 323.

Jensen, M. C. (1988). Takeovers: Their causes and consequences. Journal of Economic Perspectives, 2, 21-48.

Jensen, M. C., \& Ruback, R. S. (1983). The market for corporate control. Journal of Financial Economics, $11,5-50$.

Kini, O., Kracaw, W., \& Mian, S. (2004). The nature of discipline by corporate takeovers. Journal of Finance, 59, 1511-1552.

Langetieg, T. C. (1978). An application of a three-factor performance index to measure stochholder gains from merger. Journal of Financial Economics, 6, 365-383.

Ling, D. C., \& Ryngaert, M. (1997). Valuation uncertainty, institutional involvement, and the underpricing of IPOs: The case of REITs. Journal of Financial Economics, 43, 433-456.

Malatesta, P. H. (1983). The wealth effect of merger activity and the objective functions of merging firms. Journal of Financial Economics, 11, 155-181.

Mandelker, G. (1974). Risk and return: The case of merging firms. Journal of Financial Economics, 1, 303-335.

Martin, K. J., \& McConnell, J. J. (1991). Corporate performance, corporate takeovers, and management turnover. Journal of Finance, 46, 671-687. 
McIntosh, W., Officer, D. T., \& Born, J. A. (1989). The wealth effects of merger activities: Further evidence from real estate investment trusts. Journal of Real Estate Research, 4, 141-155.

Mikkelson, W. H., \& Partch, M. M. (1989). Managers' voting rights and corporate control. Journal of Financial Economics, 25, 263-290.

Mitchell, M. L., \& Lehn, K. (1990). Do bad bidders become good targets? Journal of Political Economy, 98, 372-398.

Moeller, S. B., Schlingemann, F. P., \& Stulz, R. M. (2004). Firm size and the gains from acquisitions. Journal of Financial Economics, 73, 201-228.

Mood, A. M., Grayhill, F. A., \& Boes, D. C. (1974). Introduction to the theory of statistics. New York: McGraw-Hill.

Morck, R., Shleifer, A., \& Vishny, R. W. (1998). Management ownership and market valuation: an empirical analysis. Journal of Financial Economics, 20, 293-315.

Myers, S. C., \& Majluf, N. S. (1984). Corporate financing and investment decisions when firms have information that investors do not have. Journal of Financial Economics, 13, 187-221.

North, D. (2001). The role of mangerial incentives in corporate acquisitions: The 1990s evidence. Journal of Corporate Finance, 7, 125-149.

Op 't Veld, H. (2005). International comparison of publicly listed companies: Does tax transparency pay? Working Paper.

Palepu, K. G. (1986). Predicting takeover targets. Journal of Accounting \& Economics, 8, 3-35.

Schleifer, A., \& Vishny, R. W. (1986). Large shareholders and corporate control. Journal of Political Economy, 94, 461-488.

Schwert, G. W. (2000). Hostility in takeovers: In the eyes of the beholder? Journal of Finance, 55, 25992640.

Servaes, H. (1991). Tobin's Q and gains from takeovers. Journal of Finance, 46, 409-419.

Shivdasani, A. (1993). Board composition, ownership structure, and hostile takeovers. Journal of Accounting \& Economics, 16, 167-198.

Sirmans, C. F. (1997). Research on REIT corporate governance. Real Estate Finance (Euromoney Institutional Investor PLC), 14, 75-79.

Smiley, R. (1976). Tender offers, transaction costs and the theory of the firm. Review of Economics \& Statistics, 58, 22-32.

Song, M. H., \& Walkling, R. A. (1993). The impact of managerial ownership on acquisition attempts and target shareholder wealth. Journal of Financial \& Quantitative Analysis, 28, 439-457.

Subrahmanyam, V., \& Rangan, N. (1997). The role of outside directors in bank acquisitions. Financial Management (Financial Management Association), 26, 23-36.

Trahan, E. A. (1993). Financial characteristics of acquiring firms and their relation to the wealth effects of acquisition announcements. Journal of Economics \& Finance, 17, 21-35.

Travlos, N. G. (1987). Corporate takeover bids, methods of payment, and bidding firm's stock returns. Journal of Finance, 42, 943-963.

Weir, C. (1997). Corporate governance, performance and take-overs: An empirical analysis of UK mergers. Applied Economics, 29, 1465-1475.

Weir, C., \& Laing, D. (2003). Ownership structure, board composition and the market for corporate control in the UK: An empirical analysis. Applied Economics, 35, 1747-1759.

Whidbee, D. A. (1997). Board composition and control of shareholder voting rights in the banking industry. Financial Management (Financial Management Association), 26, 27-41. 